\title{
New Trends Approved in Management of Dyslipidaemia
}

\author{
Abdulaziz Aboshahba ${ }^{1 *}$, Mohamed Alassal ${ }^{2}$, Ahmed G Akoush ${ }^{3}$, Areij A Osman ${ }^{4}$, Raphael C Solomo ${ }^{4}$, Mazhar \\ Ullah ${ }^{4}$, Ibrahim Eltaj ${ }^{4}$ and Aida Refaat ${ }^{5 *}$ \\ ${ }^{1}$ Doctor of medicine in cardiovascular medicine, Cardiology department, Al Azhar university, Cairo, Egypt
}

Faculty of medicine, Department of Cardiac surgery, Benha University, Egypt

${ }^{3}$ MD.NHI, Cairo, Egypt

${ }^{4}$ PAAMCC cardiac center, Arar, KSA

${ }^{5}$ Pharm D, Faculty of Pharmacy, Tanta University, Egypt

Submission: August 01, 2019; Published: August 26, 2019

*Corresponding author: Abdulaziz Aboshahba, Doctor of medicine in cardiovascular medicine, Department of Cardiology, Al Azhar university, Cairo, Egypt

Abstract

Hypercholesterolemia increases the risk of atherosclerotic cardiovascular disease and is incompletely reversed by statin therapy alone in many patients. Familial hypercholesterolemia (FH) is a common genetic cause of premature cardiovascular disease (CVD). So, most of efforts and directions focused on new therapies as PCSK9 gene was identified in the past decade as a potential therapeutic target for the management of patients with hypercholesterolemia which monoclonal antibodies, Lomitapide, Mipomersen and other therapies hoping to reduce risk of hypercholesterolemia. The novel therapies are aiming for better lipid-lowering effects, fewer side effects and improved clinical outcomes.

Keywords: Total cholesterol; HDL-cholesterol; Cell membranes; Certain hormones; Heart disease; Lipid metabolism

Abbreviations: TC: Total cholesterol; LDL: Low Density Lipoprotein; HDL: High Density Lipoprotein; TG: Triglyceride; apoB: Apolipoprotein B; FH: Familial hypercholesterolemia; ADH: Autosomal dominant hypercholesterolemia; PCSK9: Proprotein convertase subtilisin/kexin type 9; LDLR: Receptor of the LDL; ARH or FH2: Autosomal recessive hypercholesterolemia; PH: Polygenic hypercholesterolemia; VLDL: Very low-density lipoprotein; ABCA1: ATP-binding cassette transporter; apo A-1: Apolipoprotein A-I; HeFH: Heterozygous state of familial hypercholesterolemia; HoFH: Homogenous state of familial hypercholesterolemia; apo E: Apolipoprotein E; FDB: Familial defective apolipoproteinB-100; LDLRAP1: Low density lipoprotein receptor adaptor protein-1; Lp a: Lipoproteins (a); TSH: Thyroid-stimulating hormone; BUN: Blood Urea Nitrogen; CYP3A4: Cytochrome P3A4; GI: Gastro-Intestinal; ALT: Alanine aminotransferase; ECG: Electrocardiography; TR: Thyroid Receptors; CETP: Cholesterylester Transfer Protein Inhibitors; ACL: ATP-Citrate Lyase Inhibitor; ASCVD: Atherosclerotic Cardiovascular Disease; CAC: Coronary Artery Calcium; CK: Creatine Kinase; mAbs: Monoclonal antibodies; PAD: Peripheral Artery Disease; MI: Myocardial Infarction.

\section{Introduction}

\section{Hypercholesterolemia}

Elevation of total cholesterol (TC) and/or low-density lipoprotein (LDL)-cholesterol or non-HDL-cholesterol in the blood, is also often referred to as dyslipidemia, to encompass it might be accompanied by a decrease in HDL-cholesterol or an increase in triglycerides the fact that.

Dyslipidemia is classified as serum TC, LDL-cholesterol, triglyceride, apolipoprotein B (apoB), or lipoprotein (a) concentrations above the $90 \%$, or HDL-cholesterol or apolipoprotein A-I concentrations below the $10 \%$ for the general population.

\section{Cholesterol}

That comes from animals (particularly egg yolks, meat, poultry, fish, and dairy products). The body needs this substance to build cell membranes, make certain hormones, and produce compounds that aid in fat digestion (Figure 1-3).

Too much cholesterol, however, increases a person's risk of developing heart disease [1].

\section{Classification of Hypercholesterolemia}

Primary: lipid metabolism disturbances including:

Familial hypercholesterolemia (FH), which includes: 
Autosomal dominant hypercholesterolemia (ADH) by:

a) FH by mutations of receptor of the LDL (LDLR).

b) FH by familial defective apoB 100 .

c) FH by mutations of proprotein convertase subtilisin/ kexin type 9 (PCSK9) or FH3. d) Autosomal recessive hypercholesterolemia (ARH or FH2).

e) Polygenic hypercholesterolemia (PH).

f) Hyperlipoproteinemia (a).

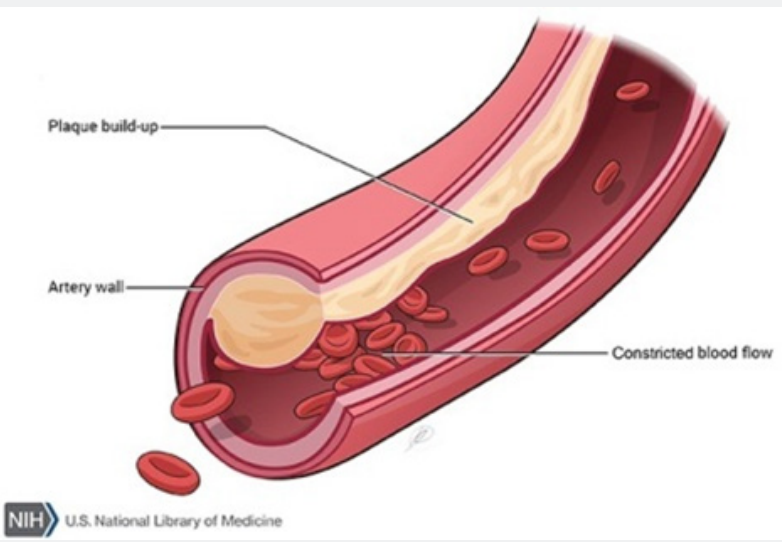

Figure 1: Artery plaque [1].

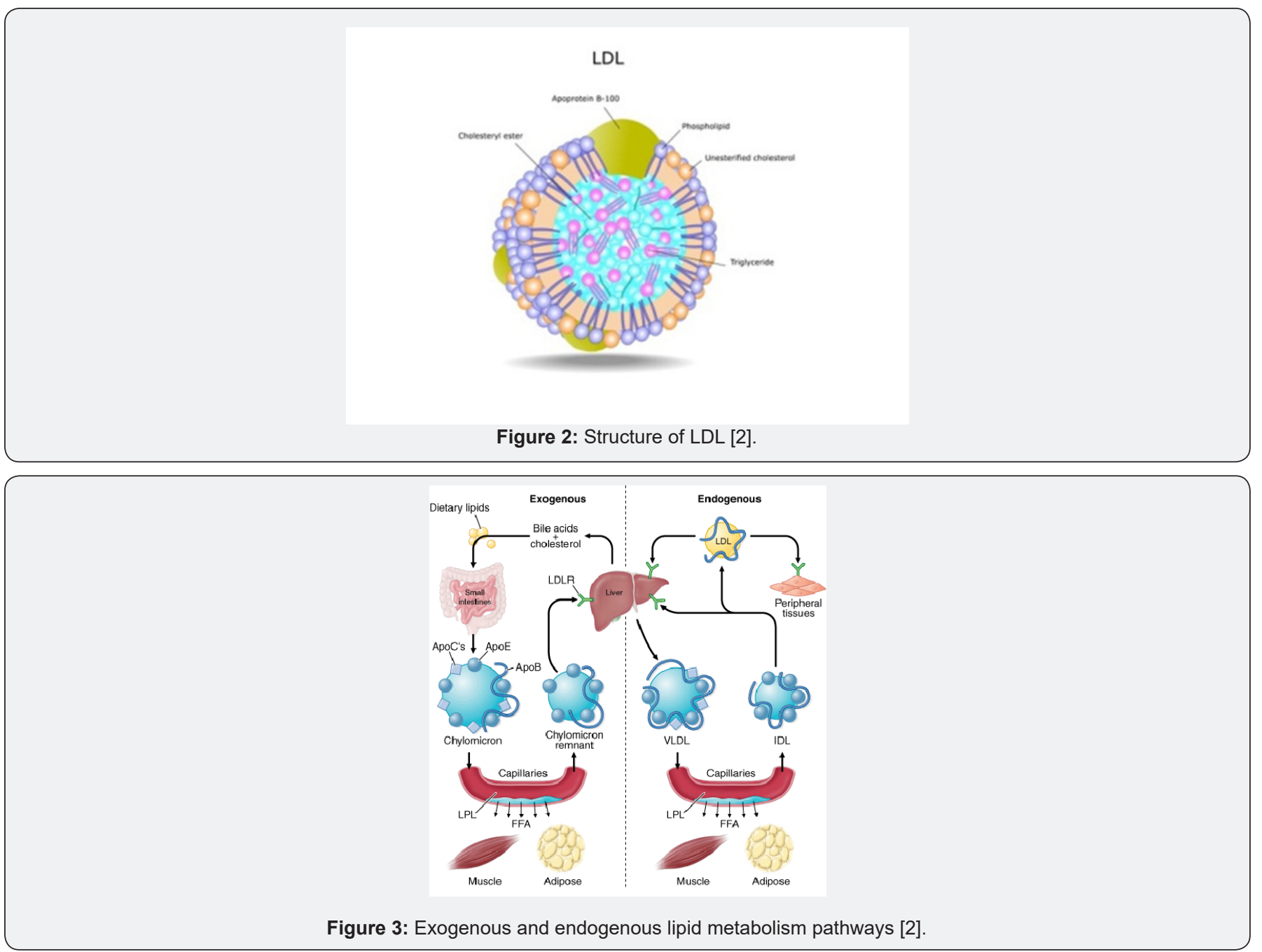


Secondary: basically, as a consequence of environmental factors or other disease causing dyslipidemia:

a) Hypothyroidism, nephrotic syndrome,

b) Cholestasis, asymptomatic acute porphyria,

c) Nervous anorexia, hepatoma,

d) Different drugs: cyclosporine, progestogens, thiazide diuretics [2-4].

\section{Classification according to: World Health Organization/ Fredrickson}

Dyslipidemia can be classified phenotypically by lipid electrophoresis based on which lipoprotein is raised.

a) Elevated chylomicrons; associated with lipoprotein lipase deficiency, apolipoprotein C-II deficiency.

b) Elevated low-density lipoprotein (LDL); associated with familial hypercholesterolemia, polygenic hypercholesterolemia, nephrosis, hypothyroidism and familial combined hyperlipidemia.

c) Elevated LDL and very low-density lipoprotein (VLDL); associated with familial combined Hyperlipidemia.

d) Elevated intermediate-density lipoprotein; associated with dysbetalipoproteinemia.

e) Elevated VLDL; associated with familial hypertriglyceridemia, familial combined hyperlipidemia, sporadic hypertriglyceridemia, abdominal obesity, diabetes.

f) Elevated chylomicrons and VLDL; associated with diabetes [5].

\section{Clinical classification}

In a more simple and practical way, dyslipidemia can also be classified as:

a) Isolated hypercholesterolemia: mostly due to LDLcholesterol elevation.

b) Mixed or combined dyslipidemia: elevations in total or LDL-cholesterol, and in triglycerides.

c) Isolated hypertriglyceridemia: elevation in triglycerides only.

d) Low HDL-cholesterol: either isolated or in association with hypercholesterolemia or hypertriglyceridemia. Causes of low HDL-cholesterol include abdominal obesity with insulin resistance, hypertriglyceridemia, smoking, and genetic diseases such as apoA-I, ABCA1 (ATP-binding cassette transporter), or lecithin-cholesterol acyltransferase deficiency [6].

\section{Familial Hypercholesterolemia}

A group of inherited genetic defects resulting in severely elevated serum cholesterol concentrations and increased risk of premature cardiovascular disease.

There are two types of FH: autosomal dominant and recessive.

a) The most common form of FH: the heterozygous state (HeFH) of $\mathrm{ADH}$, is the most frequent monogenic disorder of human metabolism [7].

b) On the contrary, homozygous $\mathrm{ADH}(\mathrm{HoFH})$ affects approximately 1:1,000,000 individuals, although recent data suggest that the prevalence could be quite higher [8].

\section{Pathophysiology}

\section{Due to decreased clearance of LDL from the plasma}

\section{Defects in the LDLR}

LDLR gene is located in chromosome 19 and codifies a membrane glycoprotein which binds to apoB and apolipoprotein E (apoE) contained in the lipoproteins [9] and play a critical role in regulating the amount of cholesterol in the blood [10].

\section{Familial defective apolipoproteinB-100 (FDB)}

Allow these particles to attach to specific receptors on the surface of cells, particularly in the liver. The receptors transport low-density lipoproteins into the cell, where they are broken down to release cholesterol. The cholesterol is then used by the cell, stored, or removed from the body [11].

\section{The PCSK9 gene mutations in chromosome 1}

That helps control blood cholesterol levels by breaking down low-density lipoprotein receptors before they reach the cell surface [12].

\section{Mutations in low density lipoprotein receptor adaptor protein-1 (LDLRAP1)}

Particularly important in the liver, that is the organ responsible for clearing most excess cholesterol from the body [13].

\section{Clinical Characteristics}
a) High plasma LDL-C levels,
b) Fatty skin deposits called xanthomas over parts of the hands, elbows, knees, ankles and around the cornea of the eye called corneal arcus.

c) Cholesterol deposits in the eye lid called xanthelasmas.

d) Coronary atheroma plaques and premature cardiovascular disease.

e) HoFH(homogenousstateoffamilial hypercholesterolemia)

f) True HoFH the LDLR pathway is markedly defective or nonfunctional.

g) The plasma LDL-C levels rise four to eight times above average $(>500 \mathrm{mg} / \mathrm{dL})$ and the patients suffer from severe cutaneous and tuberous xanthomas. 
h) In the more severe cases, cholesterol can be deposited in the tendons and joints leading to tendinitis and joint pain, requiring surgical removal.

i) In rare cases, patients could present giant ectopic cholesterol xanthomas in the brain, mediastinum, and gluteus muscles [14]. j) HeFH(heterozygousstateoffamilialhypercholesterolemia)

k) HeFH show plasma LDL-C levels two to three times above average.

l) Interaction with other genes and the presence of additional risk factors (hypertension, smoking, etc.) (Figure 4).

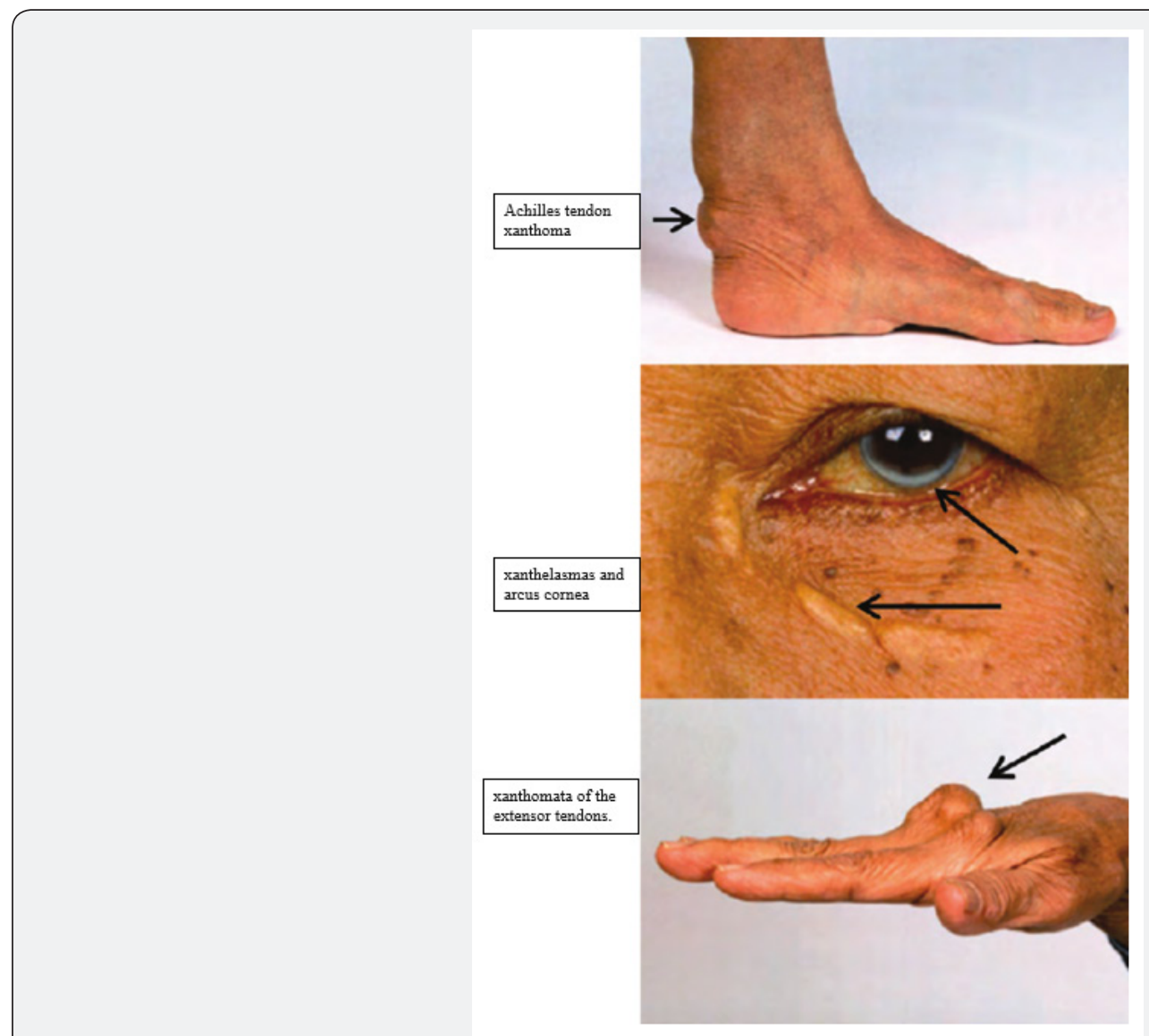

Figure 4: Clinical characteristic of hypercholesterolemia [15].

\section{Definitions}

a) Lipoprotein: the particle that transports cholesterol and triglycerides. Lipoproteins are composed of proteins (called apolipoproteins), phospholipids, triglycerides, and cholesterol.

b) The non-HDL cholesterol: the total cholesterol level minus HDL cholesterol level. It is an approximation of verylow-density lipoprotein (VLDL) plus LDL levels.

c) Myopathy: general term referring to any disease of muscles.

d) Myalgia: muscle ache or weakness without creatine kinase (CK) elevation.

e) Myositis: muscle symptoms with increased CK levels. f) Rhabdomyolysis: muscle symptoms with marked CK elevation (more than 10 times the upper limit of normal [ULN]) [15].

\section{Risk factors}

a) Multiple major coronary risk factors (especially diabetes).

b) Severe and poorly controlled risk factors (especially continued cigarette smoking).

c) Multiple risk factors of metabolic syndrome:

i. Abdominal obesity (waist circumference in men more than 40 inches $[102 \mathrm{~cm}]$ or in women more than 35 inches $[88 \mathrm{~cm}])$.

ii. Triglycerides $150 \mathrm{mg} / \mathrm{dL}$ or more. 
iii. Low HDL cholesterol (less than $40 \mathrm{mg} / \mathrm{dL}$ in men or less than $50 \mathrm{mg} / \mathrm{dL}$ in women).

iv. Blood pressure $135 / 85 \mathrm{~mm} \mathrm{Hg}$ or higher.

v. Fasting glucose $110 \mathrm{mg} / \mathrm{dL}$ or more.

d) Acute coronary syndrome [16].

e) Age: risk may increase as you get older. Men aged 45 years or older and women aged 55 years or older.

f) Gender: After menopause, a woman's LDL cholesterol level ("bad" cholesterol) goes up, as does her risk for heart disease. g) Family History: risk of high cholesterol may increase if a father or brother was affected by early heart disease (before age 55) or a mother or sister was affected by early heart disease (before age 65).

h) Diet: The trans fats, saturated fat, sugar, and (to a lesser extent) cholesterol in the food you eat raise total and LDL cholesterol levels.

i) Physical Activity: Increased physical activity helps to lower LDL cholesterol and raise HDL cholesterol (the "good" cholesterol) levels. It also helps you lose weight [17] (Figure $5)$.

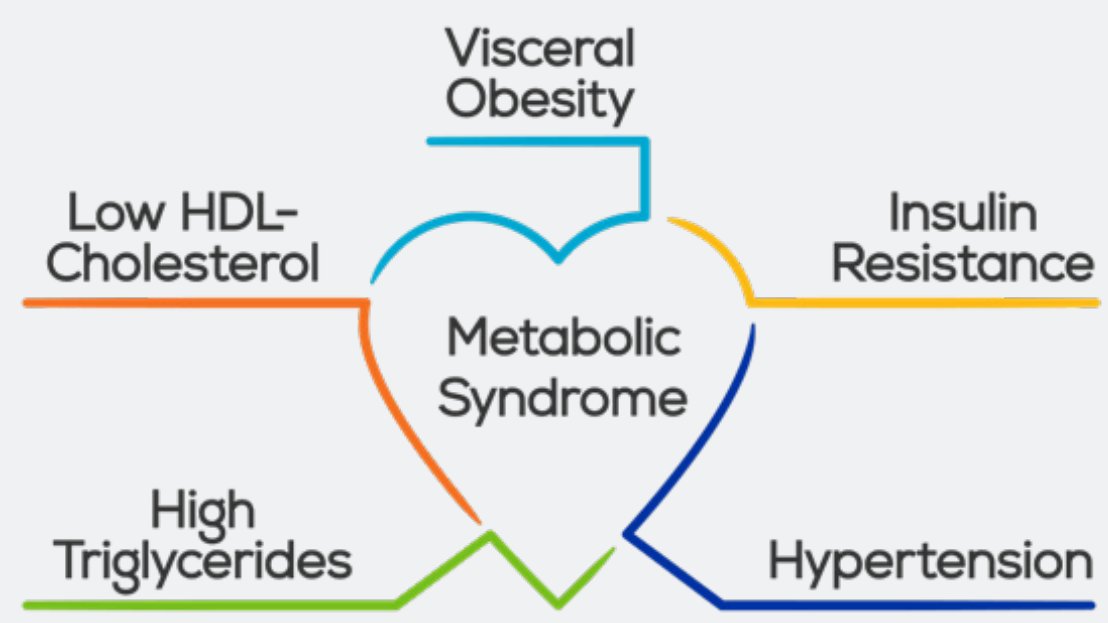

Figure 5: Multiple risk factors of metabolic syndrome [18].

\section{Diseases related to hypercholesteremia}

\section{Coronary heart disease}

Cholesterol can build up in the walls of your arteries. Over time, this build-up -- called plaque -- causes hardening of the arteries or atherosclerosis. This causes arteries to become narrowed, which slows the blood flow to the heart muscle. Reduced blood flow can result in angina (chest pain) or in a heart attack if a blood vessel gets blocked completely.

\section{Stroke}

Atherosclerosis causes arteries that lead to the brain to become narrowed and even blocked. If a vessel carrying blood to the brain is blocked completely, you could have a stroke.

\section{Peripheral vascular disease}

In this condition, fatty deposits build up along artery walls and affect blood circulation. This occurs mainly in arteries that lead to the legs and feet.

\section{Diabetes}

Diabetes can upset the balance between HDL and LDL cholesterol levels. People with diabetes tend to have LDL particles that stick to arteries and damage blood vessel walls more easily. Glucose (a type of sugar) attaches to lipoproteins (a cholesterol- protein package that enables cholesterol to travel through blood). Sugar coated LDL remains in the bloodstream longer and may lead to the formation of plaque. People with diabetes tend to have low HDL and high triglyceride (another kind of blood fat) levels. Both of these boost the risk of heart and artery disease.

\section{High blood pressure}

When the arteries become hardened and narrowed with cholesterol plaque and calcium, the heart has to strain much harder to pump blood through them. As a result, blood pressure becomes abnormally high. High blood pressure is also linked to heart disease [17].

\section{Prevention}

\section{Primary prevention}

Except for familial causes of hypercholesterolemia, the disease is completely preventable and largely related to the adoption of a healthier the lifestyle.

\section{Screening}

Lowering of low-density lipoprotein (LDL)-cholesterol leads to reduction of cardiovascular events in moderate-to-high-risk patients [18]. 
a. Screening in adults ages $>20$ years has been advocated; however, the evidence base in adults ages 21 to 39 years is not clear [19]. Previous guidance has recommended obtaining:

i. Fasting lipid profile for all adults ages $\geq 20$ years; this can be repeated every 5 years.

ii. Non-fasting lipid profile, especially for total, non-highdensity lipoprotein (HDL)-, and HDL-cholesterol, is also recommended.

iii. Screening for related cardiovascular risk factors such as hypertension, diabetes mellitus, family history of premature cardiovascular disease and smoking. There is no upper age limit at which screening for hypercholesterolemia should be terminated [20].

b. For patients $<20$ years, the presence of atherosclerotic risk factors such as hypertension, diabetes, tobacco abuse, obesity, and premature cardiovascular disease or significant hypercholesterolemia (total cholesterol $>240 \mathrm{mg} / \mathrm{dL}$ ) in the immediate family should prompt the physician to consider screening [21].

\section{Secondary prevention}

a) Dietary reduction in total and saturated fat, weight loss in overweight patients, aerobic exercise, and addition of plant stanols/sterols to the diet leads to a decrease in low-density lipoprotein cholesterol and an increase in high-density lipoprotein cholesterol.

b) In the US, evolocumab is approved for use in the reduction of risk of myocardial infarction, stroke, and coronary revascularization in adults with established cardiovascular disease.

c) Patients should be assessed for the presence of additional cardiovascular risk factors, such as smoking and diabetes, and appropriate management of these risk factors initiated [22-24].

\section{Diagnosis}

\section{History}

a) Focusing on symptoms of coronary artery disease, cerebrovascular disease, and peripheral arterial disease, such as chest pain, shortness of breath, weakness, dysphasia, or claudication.

b) Family history for early onset of coronary heart disease and dyslipidemia in first-degree relatives.

c) Level of exercise and diet at this stage.

\section{Examination}

a) Signs of hypercholesterolemia, such as eyelid xanthelasmas, arcus corneae and xanthomata. b) Tendinous xanthomas at the Achilles, elbow and knee tendons and over metacarpophalangeal joints are characteristics of heterozygous and homozygous forms of familial hypercholesterolemia.

c) Palmar or cutaneous xanthomas may be present in the homozygous form of familial hypercholesterolemia.

d) Eruptive xanthomas over the trunk, back, elbows, buttocks, knees, hands, and feet may be present in severe elevations of triglycerides.

e) Palmar and tuberous xanthomas are seen in patients with dysbetalipoproteinemia.

f) There may also be evidence of vascular disease, such as elevated neck veins or bibasal crepitations on lung auscultation (heart failure), hemiplegia (stroke), or diminished pulses (peripheral arterial disease) [17].

\section{Investigation}

a) Lipids are measured in the fasting state: including total cholesterol, triglycerides, high-density lipoprotein (HDL), and estimated low-density lipoprotein (LDL) [25,26].

b) Non-HDL-cholesterol: is a marker of cholesterol carried by pro-atherogenic lipopoproteins: very low-density lipoprotein and remnants, intermediate-density lipoproteins, LDL, and lipoproteins (a) [27].

c) LDL can be accurately estimated in non-fasting states if triglyceride levels are $<400 \mathrm{mg} / \mathrm{dl}$.

d) Extremely high lipid levels may give a lactescent (milky) appearance to blood plasma.

e) Routine thyroid-stimulating hormone rules out most cases of hypothyroidism.

f) These may include creatinine levels, fasting blood glucose and glycated hemoglobin, urinalysis, ECG, echocardiogram, cardiac stress testing, cardiac computed tomography to measure coronary calcium scores or luminal obstruction, cardiac catheterization, and vascular studies such as Doppler exam or ankle-brachial indices [17].

\section{Diagnostic tests}

\section{1st test: lipid profile}

a) Consists of TC, triglycerides, and LDL-, HDL-, and nonHDLcholesterol.

b) TC, non-HDL, and HDL can be measured in the nonfasting state [27].

c) TC values vary by $10 \%$ and triglycerides by up to $25 \%$ day to day, even in the absence of disease [28].

d) Plasma or serum can be used, with plasma cholesterol being approximately $3 \%$ higher than the serum value [29] . 
Acute illnesses can influence the lipid profile:

a) Triglycerides increase and cholesterol levels decrease in inflammatory states. In particular.

b) Lipid profiles change significantly 24 hours after an acute myocardial infarction, and measurement should either be performed acutely or postponed until after recovery [30].

\section{Result}

a) Total cholesterol (TC) $>200 \mathrm{mg} / \mathrm{dl}$.

b) LDL-cholesterol $>100 \mathrm{mg} / \mathrm{dL}$. c) Non-HDLcholesterol $>130 \mathrm{mg} / \mathrm{dL}$.

d) HDL-cholesterol $<40 \mathrm{mg} / \mathrm{dL}$ for men and $<50 \mathrm{mg} / \mathrm{dL}$ for women.

e) Triglycerides $>344 \mathrm{mg} / \mathrm{dl}$.

\section{Serum thyroid-stimulating hormone (TSH)}

a) TSH may be low in secondary hypothyroidism.

Result

a) Elevated in primary hypothyroidism $[17,31]$ (Table 1).

Table 1: Differential Diagnosis for Hypercholesterolemia.

\begin{tabular}{|c|c|c|c|c|}
\hline Condition & & Signs/Symptoms & & Tests \\
\hline Obstructive liver disease [17] & a) & $\begin{array}{l}\text { Stigmata of liver disease, such as jaundice and } \\
\text { abdominal tenderness, may be present. } \\
\text { With significant elevations of bilirubin the } \\
\text { patient may also complain of pruritus. }\end{array}$ & a) & $\begin{array}{l}\text { Elevated alanine aminotransferase, aspartate } \\
\text { aminotransferase, gammaglutamyl transfer- } \\
\text { ase, alkaline phosphatase and bilirubin. } \\
\text { Imaging studies such as abdominal ultra- } \\
\text { sound or computed tomography scan and } \\
\text { magnetic resonance imaging may show } \\
\text { dilated biliary ducts and possible cause for } \\
\text { obstruction. }\end{array}$ \\
\hline Nephrotic syndrome [17] & a) & $\begin{array}{l}\text { The hyperlipidemic response is triggered at } \\
\text { least in part by the reduction in plasma oncotic } \\
\text { pressure, and the severity of the hyperlipid- } \\
\text { emia is inversely and closely related to the fall } \\
\text { in oncotic pressure. } \\
\text { Spontaneous or drug induced resolution of } \\
\text { nephrotic syndrome reverses hyperlipidemia. }\end{array}$ & a) & $\begin{array}{l}\text { Marked elevations in plasma levels of cho- } \\
\text { lesterol and less predictably, triglycerides } \\
\text { and lipoprotein (a). High-density lipoprotein } \\
\text { (HDL)-cholesterol usually normal or reduced. } \\
\text { Abnormal serum creatinine, BUN, and serum } \\
\text { albumin. } \\
\text { c) Elevated 24-hour urinary protein. }\end{array}$ \\
\hline $\begin{array}{l}\text { Chronic renal } \\
\text { Insufficiency [17] }\end{array}$ & a) & $\begin{array}{l}\text { Dyslipidemia normally presents as hypertri- } \\
\text { glyceridemia (due to diminished clearance). } \\
\text { Low HDL-cholesterol levels are also seen in } \\
\text { many patients. } \\
\text { Patients undergoing peritoneal dialysis are } \\
\text { more likely to have an atherogenic lipid profile } \\
\text { than those undergoing hemodialysis. }\end{array}$ & $\begin{array}{l}\text { b) } \\
\text { c) } \\
\text { e) }\end{array}$ & $\begin{array}{l}\text { About half of patients have triglyceride levels } \\
>200 \mathrm{mg} / \mathrm{dL} \text {, about one third have total } \\
\text { cholesterol levels }>240 \mathrm{mg} / \mathrm{dL} \text {, and } 10 \% \text { to } \\
45 \% \text { have low-density lipoprotein cholesterol } \\
\text { levels }>130 \mathrm{mg} / \mathrm{dL} \text {. } \\
\text { Total cholesterol concentration is sometimes } \\
\text { normal or low, which may be in part due to } \\
\text { malnutrition in this subset of patients. } \\
\text { Abnormal serum creatinine, BUN, and serum } \\
\text { albumin. } \\
\text { d) Elevated } 24 \text {-hour urinary protein. } \\
\text { Estimated glomerular filtration rate should } \\
\text { be calculated. }\end{array}$ \\
\hline Hypothyroidism [31] & $\begin{array}{l}\text { a) } \\
\text { b) } \\
\text { c) }\end{array}$ & $\begin{array}{l}\text { There may be lethargy, cold intolerance, con- } \\
\text { stipation, dry hair or skin, goiter, or delayed } \\
\text { return of deep tendon reflexes. } \\
\text { In a study investigating people referred for the } \\
\text { evaluation of hyperlipidemia, hypothyroidism } \\
\text { was found to be present in } 4.2 \% \text { of patients. } \\
\text { A significant reduction in the serum choles- } \\
\text { terol concentration during thyroid hormone } \\
\text { replacement was only seen in those patients } \\
\text { with a serum thyroidstimulating hormone } \\
\text { (TSH) concentration }>10 \text { milliunits/L. }\end{array}$ & a) & $\begin{array}{c}\text { Serum TSH is high and serum free thyroxine } \\
\text { may be low. }\end{array}$ \\
\hline
\end{tabular}

Table 2: Classification of LDL-C, Total cholesterol, Triglycerides and HDL-C.

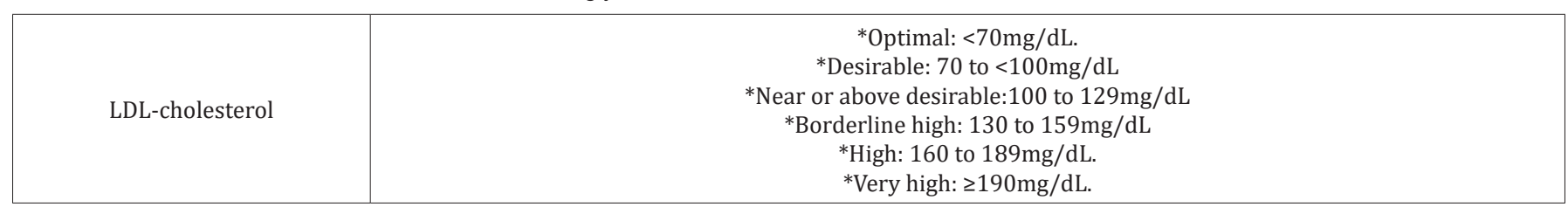




\begin{tabular}{|c|c|}
\hline Total cholesterol & $\begin{array}{c}\text { *Optimal: }<170 \mathrm{mg} / \mathrm{dL} \\
\text { *Desirable: }<200 \mathrm{mg} / \mathrm{dL} \\
\text { *Borderline high: } 200 \text { to } 239 \mathrm{mg} / \mathrm{dL} \\
\text { *High: } \geq 240 \mathrm{mg} / \mathrm{dL} .\end{array}$ \\
\hline Triglycerides & $\begin{array}{c}\text { *Ideal: }<100 \mathrm{mg} / \mathrm{dL} \\
\text { *Desirable: } 100 \text { to }<150 \mathrm{mg} / \mathrm{dL} \\
\text { *Borderline high: } \geq 150 \mathrm{mg} / \mathrm{dL} \\
\text { *High: } 200 \text { to } 499 \mathrm{mg} / \mathrm{dL} \\
\text { *Very high: } \geq 500 \mathrm{mg} / \mathrm{dL} .\end{array}$ \\
\hline HDL-cholesterol & *Low: $<40 \mathrm{mg} / \mathrm{dL}$. \\
\hline
\end{tabular}

\section{Diagnostic criteria}

Classification of low-density lipoprotein (LDL)-cholesterol, total cholesterol, triglycerides, and high-density lipoprotein (HDL) cholestero $\lambda$ [32,33] (Table 2).

Table 3: Classification of Non-HDL-C.

\begin{tabular}{|c|}
\hline a) In low- to moderate-risk patients, high non-HDL-cholesterol: $\geq 145 \mathrm{mg} / \mathrm{dL}$. \\
\hline b) In high-risk patients, high non-HDL-cholesterol: $\geq 130 \mathrm{mg} / \mathrm{dL}$. \\
\hline c) In very high-risk patients, high non-HDL-cholesterol: $\geq 100 \mathrm{mg} / \mathrm{dL}$. \\
\hline
\end{tabular}

\section{Discussion}

Top 10 Take-Home Messages to Reduce Risk of Atherosclerotic Cardiovascular Disease Through Cholesterol Management:

In all individuals, emphasize a heart-healthy lifestyle across the life course.

A healthy lifestyle reduces atherosclerotic cardiovascular disease (ASCVD) risk at all ages. In younger individuals, healthy lifestyle can reduce development of risk factors and is the foundation of ASCVD risk reduction. Lifestyle therapy is the primary intervention for metabolic syndrome.

In patients with clinical ASCVD, reduce low-density lipoprotein cholesterol (LDL-C) with high intensity statin therapy or maximally tolerated statin therapy.

The more LDL-C is reduced on statin therapy, the greater will be subsequent risk reduction. Use a maximally tolerated statin to lower LDLC levels by $\geq 50 \%$.

In very high-risk ASCVD, use a LDL-C threshold of $70 \mathrm{mg} / \mathrm{dL}(1.8 \mathrm{mmol} / \mathrm{L})$ to consider addition of nonstatins to statin therapy.

Very high-risk includes a history of multiple major ASCVD events or 1 major ASCVD event and multiple high-risk conditions. In very high-risk ASCVD patients, it is reasonable to add ezetimibe to maximally tolerated statin therapy when the LDL-C level remains $\geq 70 \mathrm{mg} / \mathrm{dL}(\geq 1.8 \mathrm{mmol} / \mathrm{L})$. In patients at very high risk whose LDL-C level remains $\geq 70 \mathrm{mg} / \mathrm{dL}$ ( $\geq 1.8 \mathrm{mmol} / \mathrm{L}$ ) on maximally tolerated statin and ezetimibe therapy, adding a PCSK9 inhibitor.

In patients with severe primary hypercholesterolemia (LDL-C level $\geq 190 \mathrm{mg} / \mathrm{dL}$ [ $\geq 4.9 \mathrm{mmol} / \mathrm{L}]$ ), without calculating 10-year ASCVD risk, begin high-intensity statin therapy without calculating 10- year ASCVD risk.

\section{Classification of non-HDL-cholesterol}

Non-HDL-cholesterol is considered high depending on the level of cardiovascular disease risk [34] (Table 3).
If the LDL-C level remains $\geq 100 \mathrm{mg} / \mathrm{dL}(\geq 2.6 \mathrm{mmol} / \mathrm{L})$, adding ezetimibe is reasonable. If the LDL-C level on statin plus ezetimibe remains $\geq 100 \mathrm{mg} / \mathrm{dL}(\geq 2.6 \mathrm{mmol} / \mathrm{L})$ and the patient has multiple factors that increase subsequent risk of ASCVD events, a PCSK9 inhibitor.

In patients 40 to 75 years of age with diabetes mellitus and $\mathrm{LDL}-\mathrm{C} \geq 70 \mathrm{mg} / \mathrm{dL}(\geq 1.8 \mathrm{mmol} / \mathrm{L})$, start moderateintensity statin therapy without calculating 10-year ASCVD risk.

In patients with diabetes mellitus at higher risk, especially those with multiple risk factors or those 50 to 75 years of age, it is reasonable to use a high-intensity statin to reduce the LDL-C level by $\geq 50 \%$.

In adults 40 to 75 years of age evaluated for primary ASCVD prevention, have a clinician-patient risk discussion before starting statin therapy.

Risk discussion should include a review of major risk factors (e.g., cigarette smoking, elevated blood pressure, LDL-C, hemoglobin A1C [if indicated] and calculated 10-year risk of ASCVD), the presence of risk-enhancing factors, the potential benefits of lifestyle and statin therapies, the potential for adverse effects and drug-drug interactions, consideration of costs of statin therapy, patient preferences and values in shared decision making.

In adults 40 to 75 years of age without diabetes mellitus and with LDL-C levels $\geq 70 \mathrm{mg} / \mathrm{dL}(\geq 1.8 \mathrm{mmol} / \mathrm{L})$, at a 10 year ASCVD risk of $\geq 7.5 \%$, start a moderate-intensity statin if a discussion of treatment options favors statin therapy.

Risk-enhancing factors favor statin therapy. If risk status is uncertain, consider using coronary artery calcium (CAC) to improve specificity. If statins are indicated, reduce LDL-C levels by $\geq 30 \%$, and if 10 -year risk is $\geq 20 \%$, reduce LDL-C levels by $\geq 50 \%$. 
In adults 40 to 75 years of age without diabetes mellitus and 10 -year risk of $7.5 \%$ to $19.9 \%$ (intermediate risk), risk-enhancing factors favour initiation of statin therapy.

Risk enhancing factors include:

a) Family history of premature ASCVD.

b) Persistently elevated LDL-C levels $\geq 160 \mathrm{mg} / \mathrm{dL}$ $(\geq 4.1 \mathrm{mmol} / \mathrm{L})$.

c) Metabolic syndrome; chronic kidney disease; history of preeclampsia or premature menopause (age $<40$ years); chronic inflammatory disorders (rheumatoid arthritis, psoriasis, or chronic HIV).

d) Persistent elevations of triglycerides $\geq 175 \mathrm{mg} / \mathrm{dL}$ ( $\geq 1.97 \mathrm{mmol} / \mathrm{L}$ ) and if measured in selected individuals apolipoprotein B $\geq 130 \mathrm{mg} / \mathrm{dL}$, high-sensitivity C-reactive protein $\geq 2.0 \mathrm{mg} / \mathrm{L}$, ankle-brachial index $<0.9$ and lipoprotein (a) $\geq 50 \mathrm{mg} / \mathrm{dl}$ or $125 \mathrm{nmol} / \mathrm{L}$, especially at higher values of lipoprotein (a).

e) Risk-enhancing factors may favour statin therapy in patients at 10-year risk of 5-7.5\% (borderline risk).
In adults 40 to 75 years of age without diabetes mellitus and with LDL-C levels $\geq 70 \mathrm{mg} / \mathrm{dL}-189 \mathrm{mg} / \mathrm{dL}$ ( $\geq 1.8-4.9$ $\mathrm{mmol} / \mathrm{L}$ ), at a 10 -year ASCVD risk of $\geq 7.5 \%$ to $19.9 \%$, if a decision about statin therapy is uncertain, consider measuring CAC.

If CAC is zero, treatment with statin therapy may be withheld or delayed, except in cigarette smokers, those with diabetes mellitus, and those with a strong family history of premature ASCVD. A CAC score of 1 to 99 favours statin therapy, especially in those $\geq 55$ years of age. For any patient, if the CAC score is $\geq 100$ Agatston units or $\geq 75 \%$, statin therapy is indicated unless otherwise deferred by the outcome of clinician-patient risk discussion.

Assess adherence and percentage response to LDL-Clowering medications and lifestyle changes with repeat lipid measurement 4 to 12 weeks after statin initiation or dose adjustment, repeated every 3 to 12 months as needed.

Define responses to lifestyle and statin therapy by percentage reductions in LDL-C levels compared with baseline. In ASCVD patients at very high-risk, triggers for adding nonstatin drug therapy are defined by threshold LDL-C levels $\geq 70 \mathrm{mg} / \mathrm{dL}$ ( $\geq 1.8 \mathrm{mmol} / \mathrm{L}$ ) on maximal statin therapy [35].

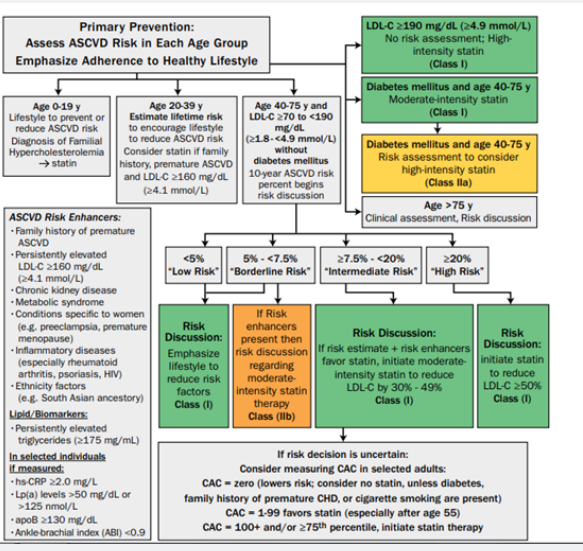

Figure 6: Primary prevention.

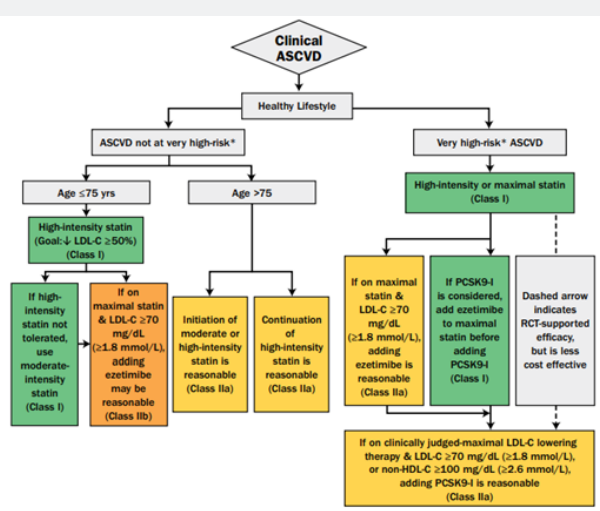

Figure 7: Secondary prevention. 


\section{Treatment targets}

a) Reduce atherosclerotic CV risk in adults.

b) The importance of LDL-C lowering to prevent CVD is strongly emphasized.

Smoking: No exposure to tobacco in any form.

Diet: Healthy diet low in saturated fat with a focus on whole grain products, vegetables, fruit and fish.

Physical activity: 2.5-5h moderately vigorous physical activity per week or $30-60 \mathrm{~min}$ most days.

Body weight: BMI $20-25 \mathrm{~kg} / \mathrm{m} 2$, waist circumference $<94 \mathrm{~cm}$ (men) and $<80 \mathrm{~cm}$ (women).

Blood pressure: $<140 / 90 \mathrm{mmHg}$.

Lipids LDL-C is the primary target:

a) Very high-risk: LDL-C $<1.8 \mathrm{mmol} / \mathrm{L}(70 \mathrm{mg} / \mathrm{dL})$ or a reduction of at least $50 \%$ if the baseline is between 1.8 and $3.5 \mathrm{mmol} / \mathrm{L}$ (70 and $135 \mathrm{mg} / \mathrm{dL}$ ).

b) High-risk: LDL-C $<2.6 \mathrm{mmol} / \mathrm{L}(100 \mathrm{mg} / \mathrm{dL})$ or a reduction of at least $50 \%$ if the baseline $\mathrm{b}$ is between 2.6 and $5.2 \mathrm{mmol} / \mathrm{L}(100$ and $200 \mathrm{mg} / \mathrm{dL})$.

c) Low to moderate risk: LDL-C $<3 \mathrm{mmol} / \mathrm{L}(115 \mathrm{mg} / \mathrm{dL})$.

d) Non-HDL-C secondary targets are $<2.6,3.4$ and 3.8 $\mathrm{mmol} / \mathrm{L}$ (100, 130 and 145mg/dL) for very high-, high- and moderate-risk subjects, respectively.

e) HDL-C: no target, but $>1 \mathrm{mmol} / \mathrm{L}(40 \mathrm{mg} / \mathrm{dL})$ in men and $>1.2 \mathrm{mmol} / \mathrm{L}(48 \mathrm{mg} / \mathrm{dL})$ in women indicates lower risk.

f) TG: no target but $<1.7 \mathrm{mmol} / \mathrm{L}(150 \mathrm{mg} / \mathrm{dL})$ indicates lower risk and higher levels indicate a need to look for other risk factors.

g) Diabetes: HbA1c $<7 \%(<53 \mathrm{mmol} / \mathrm{mol})[35]$ (Figure $6 \&$ 7).

\section{Treatment}

a) Primary prevention over life span [35].

b) Secondary ASCVD Prevention [35].

c) Pharmacological treatment

d) Lipid-Lowering Drugs

\section{Statin}

\section{Mechanism of action}

Statins reduce synthesis of cholesterol in the liver by competitively inhibiting HMG-CoA reductase activity. The reduction in intracellular cholesterol concentration induces lowdensity lipoprotein receptor (LDLR) expression on the hepatocyte cell surface, which results in increased LDL-C catabolism and a decreased LDL-C synthesis and other apo B-containing lipoproteins including TG-rich particles [36].

\section{Side effects}

a) Myopathy.

b) Elevated liver enzymes (rarely hepatotoxicity).

c) Muscle cell damage and death (rhabdomyolysis) result in the release of creatine phosphokinase (CK) and myoglobin among other intracellular molecules, while the accumulation of myoglobin in the kidneys can lead to renal failure and death [37-42] (Table 4).

Table 4: High, Moderate and Low Intensity of Statin [35].

\begin{tabular}{|c|c|c|c|}
\hline & High-Intensity & Moderate Intensity & Low Intensity \\
\hline LDL-C lowering & $\geq 50 \%$ & $30 \%-49 \%$ & $<30 \%$ \\
\hline \multirow{9}{*}{ Statins } & * Atorvastatin $40-80 \mathrm{mg}$ & * Atorvastatin $10-20 \mathrm{mg}$ & \\
\hline & * Rosuvastatin 20-40 mg. & * Rosuvastatin 5-10mg. & * Simvastatin 10mg. \\
\hline & & * Simvastatin $20-40 \mathrm{mg}$ & \\
\hline & & * Pravastatin 40-80mg. & \\
\hline & & * Lovastatin 40-80mg. & \\
\hline & & * Fluvastatin XL 80mg. & $*$ Pravastatin $10-20 \mathrm{mg}$. \\
\hline & & * Flyvastatin 40mg. & * Lovastatin 20mg. \\
\hline & & (BID). & * Fluvastatin $20-40 \mathrm{mg}$. \\
\hline & & * Pitavastatin 1-4mg. & \\
\hline
\end{tabular}

\section{Non-Statin Therapy}

\section{Newtrendsapprovedintreatmentofhypercholesterolemia}

The potential role of certain additional options, including microsomal transfer protein inhibitors, liver-selective thyroid hormone mimetics, and oligonucleotides that supress ApoB $[43,15]$ (Table 5).

\section{Lomitapide}

\section{Mechanism of action}

Inhibiting the microsomal triglyceride transfer protein in the liver, that is necessary for TG absorption by the chylomicrons in the intestine and phospholipids by VLDL in the hepatocytes [44]. 
Table 5: Non-Statin Therapies of Hypercholesterolemia.

\begin{tabular}{|c|c|c|}
\hline Drug & МOA[36] & Effect[35] \\
\hline \multirow[t]{2}{*}{$\begin{array}{l}\text { Ezetimibe } \\
\text { (Cholesterol } \\
\text { Absorption } \\
\text { Inhibitors) }\end{array}$} & $\begin{array}{l}\text { * The first lipid-lowering drug that inhibits intestinal } \\
\text { uptake of dietary and biliary cholesterol without affecting } \\
\text { the absorption of fat-soluble nutrients. } \\
\text { * Blocks cholesterol absorption across the intestinal } \\
\text { border. } \\
\text { * Ezetimibe is the most commonly used non-statin agent. }\end{array}$ & $\begin{array}{l}\quad \text { * Lowers cholesterol. } \\
* \text { It lowers LDL-C levels by } 13 \% \text { to } 20 \% \text {. }\end{array}$ \\
\hline & \multicolumn{2}{|c|}{ a) Has a low incidence of side effect. } \\
\hline \multirow[t]{2}{*}{$\begin{array}{l}\text { Bile acid } \\
\text { sequestrants } \\
\text { (Chole- } \\
\text { styramine, } \\
\text { colestipol and } \\
\text { colsevelam) }\end{array}$} & $\begin{array}{l}\text { * Bile acids are synthesized in the liver from cholesterol. } \\
\quad * \text { Increased LDL catabolism. } \\
\quad * \text { Reduced cholesterol absorption. }\end{array}$ & $\begin{array}{c}\text { * Reduce cholesterol. } \\
\text { * Increase VLDL. } \\
\text { * Reduce LDL-C levels by } 15 \% \text { to } 30 \% \text { depending on the dose. } \\
\text { N.B: } \\
\text { * Not absorbed and do not cause systemic side effects, but they are } \\
\text { associated with gastrointestinal complaints (e.g., constipation). } \\
\text { * Cause severe hypertriglyceridemia when fasting triglycerides are } \\
\geq 300 \mathrm{mg} / \mathrm{dl}(\geq 3.4 \mathrm{mmol} / \mathrm{L}) .\end{array}$ \\
\hline & $\begin{array}{l}\text { a) In the management of FH, bile acid sequestrants } 1 \\
\text { nant women or women who want to be } \\
\text { b) Combination therapy wi }\end{array}$ & $\begin{array}{l}\text { ay be recommended either as monotherapy in younger patients, preg- } \\
\text { me pregnant and patients requiring modest LDL reduction. } \\
\text { statins in patients with very high LDL levels. }\end{array}$ \\
\hline \multirow[t]{2}{*}{$\begin{array}{l}\text { Nicotinic acid } \\
\text { (Vitamin B3) }\end{array}$} & $\begin{array}{l}\text { * Has broad lipid-modulating action. } \\
{ }^{*} \text { Reduce LDL and VLDL synthesis. }\end{array}$ & $\begin{array}{l}\text { * Raising HDL-C by } 25 \% \\
* \text { Reducing LDL-C by } 15-18 \% \text {. } \\
\text { * Reducing TG by } 20-40 \% \text { at the } 2 \mathrm{~g} / \text { day dose. } \\
* \text { Lowering Lp(a) levels by up to } 30 \% \text { at this dose. }\end{array}$ \\
\hline & $\begin{array}{l}\text { a) Nicotinic acid has also been shown to } \\
\text { b) Increased ri }\end{array}$ & $\begin{array}{l}\text { duce insulin sensitivity and impair glucose control in T2DM patients. } \\
\text { of myopathy when combined with statins. }\end{array}$ \\
\hline \multirow{2}{*}{$\begin{array}{l}\text { Fibrates } \\
\text { (Gemfibrozil, } \\
\text { fenofibrate } \\
\text { and clofi- } \\
\text { brate) }\end{array}$} & $\begin{array}{l}\text { * Increased VLDL clearance. } \\
\quad \text { * Reduce LDL synthesis. }\end{array}$ & $\begin{array}{l}\text { * Reduce TG. } \\
\text { * Reduce cholesterol. } \\
\text { * Reduce LDL, VLDL. } \\
\text { * Increase HDL. }\end{array}$ \\
\hline & \multicolumn{2}{|c|}{$\begin{array}{l}\text { a) The addition of fibrates to statins has been associated with higher incidence of myopathy, rhabdomyolysis and liver } \\
\text { dysfunction. } \\
\text { b) Gemfibrozil should not be co-prescribed with statins. }\end{array}$} \\
\hline Fish Oil & \multicolumn{2}{|c|}{$\begin{array}{l}\text { * Less atherogenic lipid profile in FH patients [38,39]. } \\
\quad * \text { Cardio-protective. } \\
\text { * Reducing arterial stiffness and improving blood pressure [40,41]. } \\
\text { nt meta-analysis reported a weakness of fish oils to achieve significant positive outcomes [42]. }\end{array}$} \\
\hline
\end{tabular}

Table 6: Effect of Lomitapide on LDL and LP(a) [46].

\begin{tabular}{|c|c|c|}
\hline LDL reduced & By $50 \%$ at 26 week of treatment. & $*$ Its effect on LDL maintained from 26 to 78 weeks of treatment. \\
\hline Lipoprotein(a) reduced & By $15 \%$ at 26 week of treatment. & ${ }^{*}$ Lp(a) levels return back to baseline at week 78. \\
\hline
\end{tabular}

a) Co-administration of Lomitapide with cytochrome P3A4 (CYP3A4) inhibitors should be avoided [44].

b) Increased hepatic fat content and elevation of transaminases, which resolved after dose reduction [45].

c) Gastro-Intestinal (GI) adverse events $[45,46]$ which may be resolved by slow dose titration, low-fat diet, and avoidance of mealtimes [44,46,47] (Table 6).

\section{Mipomersen}

\section{Mechanism of action}

Antisense oligonucleotide that binds ApoB mRNA and subsequently down regulates the expression of $A p o B$ by the ribosomes and the production of VLDL $[44,48]$.
Notes:

a) Administered as a $200 \mathrm{mg}$ subcutaneous once-weekly injection [49].

b) Lowering lipid in pediatric [50].

c) The most common adverse effect:

d) Injection-site reactions.

e) Flu-like symptoms.

f) Elevated ALT $(<3 \times$ URL $)[51,52]$.

g) Increased intrahepatic TG content $[53,54]$ (Table 7). 
Table 7: Effect of Mipomersen in Lipid.

\begin{tabular}{|l|c|}
\hline \multirow{2}{*}{$\begin{array}{c}\text { LDL level reduced by } \\
\text { The maximum tolerated standard lipid-lowering treatment in HoFH } \\
\text { patients: }\end{array}$} & $* 21 \%$ in patients with HoFH. \\
\cline { 2 - 2 } & $* 28 \%$ in HeFH.[55] \\
\cline { 2 - 2 } & $*$ LDL reduced by $25 \%$. \\
\hline
\end{tabular}

\section{Thyroid Mimetics}

\section{Mechanism of action}

Thyroid hormones act on two main types of receptors, thyroid receptors $\alpha$ and $\beta$ (TR $\alpha$ and TR $\beta$ ) [55,56]. Endogenous thyroid hormones having Lipid-Lowering effects through TR $\beta$; but not be utilized due to TR $\alpha$-induced cardiac, muscle and bone thyrotoxic side effects $[57,56]$.

Selective TR $\beta$ agonists could offer an additional approach in HF treatment by induction hepatic bile acid production and upregulation the expression of the HDL receptor, the receptor type B-Class I (SR-B1), leading to increased transport of cholesterol into
HDL particles [57]. These agents can interfere with cholesterol metabolism, without the unwanted TR $\alpha$-related side effects [55].

Selective TR $\beta$ agonists (GC-1 (sobetirome) and KB2115 (eprotirome)) decrease serum cholesterol levels by increasing cholesterol utilization for synthesis of bile acids and inducing their subsequent fecal excretion in an LDLR-independent manner [57].

Notes: Due to the reported side effects, the future role of thyroid mimetics will depend on their safety profile and some of these agents may potentially find a role in HoFH treatment [56] (Table 8).

Table 8: Characteristics of Thyromimetics Eprotirome and Sobetirome.

\begin{tabular}{|c|c|c|}
\hline Drug & Lipid effect & Side effect \\
\hline Eprotirome (KB2115) & $\begin{array}{l}\text { * Dose-dependent LDL lowering effect. } \\
\qquad 22 \% \text { LDL reduction [59]. }\end{array}$ & $\begin{array}{l}\text { * induced cartilage damage [59]. } \\
\text { * induced liver injury }\end{array}$ \\
\hline \multirow[t]{2}{*}{ Sobetirome (GC-1) } & * Remarkable LDL reduction. & $\begin{array}{l}\text { Mild suppression of the hypothalamic-pituitary } \\
\text { axis. [57] }\end{array}$ \\
\hline & * decreased TG and Lp(a) levels. & \\
\hline
\end{tabular}

\section{Proprotein Convertase Subtilisin/Kexin 9 (PCSK9) Inhibitors}

\section{Mechanism of action}

PCSK9 is a serine protease produced by hepatocytes [48] blocks the LDLR recycling by mediating clathrinmediated endocytosis and subsequently inducing the lysosomatic degradation of LDLR $[58,59]$ and this leads to LDL accumulation in the circulation [60] and eventually promotes atherogenesis, with high PCSK9 levels correlating to the degree of coronary artery calcification [61].
The strategies that target the binding include:

a) Monoclonal antibodies (mAbs) that bind to PCSK9 in the plasma, thereby preventing it from binding to LDL-R.

b) Modified binding proteins such as adnectins, and smallmolecule inhibitors. Notably, development of a small-molecule inhibitor of PCSK9 [62].

a) Effect:

LDL reduction: up to a $55 \%$ as monotherapy, and $75 \%$ combined with a statin [63-68] (Figure 8) \& (Table $9 \& 10$ ).

Table 9: Monoclonal antibodies PSCK9 Inhibitors.

\begin{tabular}{|c|c|c|}
\hline \multicolumn{2}{|r|}{ Alirocumab } & Evolocumab \\
\hline b) & $\begin{array}{l}\text { Administrated subcutaneously every } 2 \text { weeks }[65,66] \text {. } \\
\text { Showed significant and persistent reductions in LDL, non- } \\
\text { HDL cholesterol, and Lp(a) levels }[67,68,69] .\end{array}$ & $\begin{array}{l}\text { c) Administrated subcutaneously every } 4 \text { weeks } \\
{[65,66] \text {. }} \\
\text { a) Treatment for both HeFH and HoFH. } \\
\text { b) Used in statin-intolerant patients and for } \\
\text { significantly lowering LDL. } \\
\text { d) Improves ApoA1, ApoB, Lp(a), non-HDL cho- } \\
\text { lesterol, and triglycerides [67]. }\end{array}$ \\
\hline \multicolumn{3}{|c|}{$\begin{array}{l}\quad \text { Side Effects: } \\
\text { e) Mild injectionsite reactions [15]. } \\
\text { piratory tract infections, back pain and influenza [71]. } \\
\text { Very rarely leucocytoclastic vasculitis [15]. }\end{array}$} \\
\hline
\end{tabular}

Two additional PCSK9 inhibitors:

a) Bococizumab

b) LY3015014 [72]. 
Table 10: Monoclonal antibodies PSCK9 Inhibitors.

\begin{tabular}{|c|c|}
\hline ACC (2016-updated in 2017) & ESC/EAS (2017-updated in 2018) \\
\hline $\begin{array}{c}\text { Specific criteria: } \\
\text { ASCVD without comorbidities and LDL } \\
\geq 2.6 \mathrm{mmol} / \mathrm{L}(100 \mathrm{mg} / \mathrm{dL}) \text { while on maximum } \\
\text { tolerated statin and ezetimibe and a reduction } \\
\text { of LDL }<50 \% \text { from baseline. } \\
\text { 2. ASCVD with comorbidities and LDL } \geq 1.8 \mathrm{mmol} / \mathrm{l} \\
\text { (70mg/dL), or non-HDL } \geq 2.6 \mathrm{mmol} / \mathrm{L}(100 \mathrm{mg} / \\
\text { dL) in diabetic patients, while on maximum } \\
\text { tolerated statin and ezetimibe and a reduction } \\
\text { of LDL }<50 \% \text { from baseline. } \\
\text { ASCVD with baseline } \mathrm{LDL} \geq 4.9 \mathrm{mmol} / \mathrm{L} \\
\text { (190mg/dL) and post-treatment LDL } \\
\geq 1.8 \mathrm{mmol} / \mathrm{l}(70 \mathrm{mg} / \mathrm{dL}) \text { while on maximum } \\
\text { tolerated statin and a reduction of LDL }<50 \% \text {, } \\
\text { as an alternative to ezetimibe or bile acid } \\
\text { sequestrant. } \\
\text { Without ASCVD and LDL } \geq 4.9 \mathrm{mmol} / \mathrm{L}(190 \mathrm{mg} / \\
\text { dL) and post-treatment LDL } \geq 2.6 \mathrm{mmol} / \mathrm{l} \\
\text { (100mg/dL) while on maximum tolerated statin } \\
\text { and a reduction of LDL }<50 \% \text {, as an alternative } \\
\text { to ezetimibe or bile acid sequestrant. } \\
\text { Before LDL apheresis in HoFH patients, except } \\
\text { LDLR negative patients. }\end{array}$ & 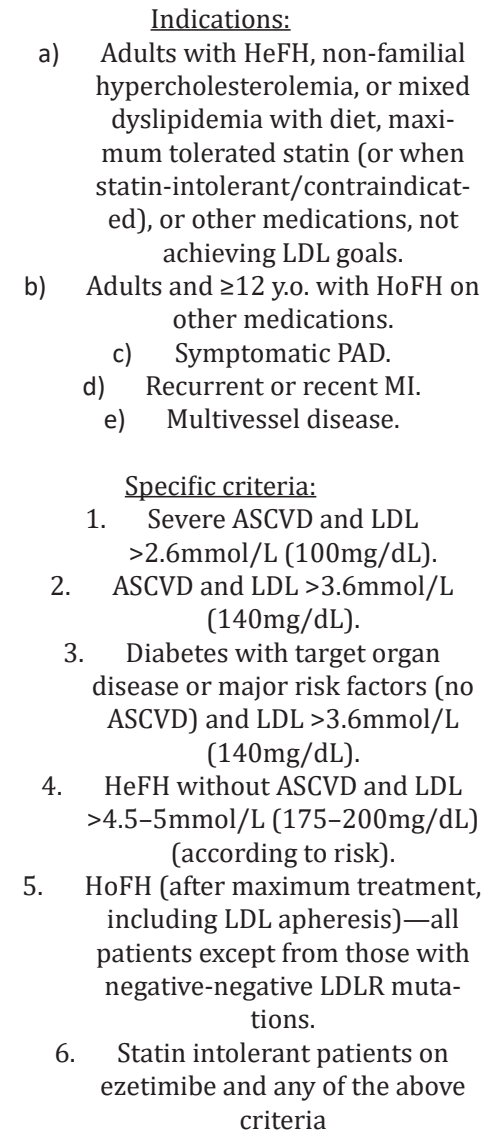 \\
\hline
\end{tabular}

Table 11: Types of CETP.

\begin{tabular}{|c|c|}
\hline Drug & Effect \\
\hline Anacetrapib & $*$ Interferes with lipid exchange. \\
& $\begin{array}{c}* \text { Reduces LDL by increasing ApoB100-LDL binding to LDLR. } \\
* \text { Removing ApoB from the circulation [75]. }\end{array}$ \\
\hline Torcetrapib & $*$ Increase HDL by $72.1 \%$. \\
& $*$ Lower LDL by 24.9\% [76]. \\
\hline
\end{tabular}

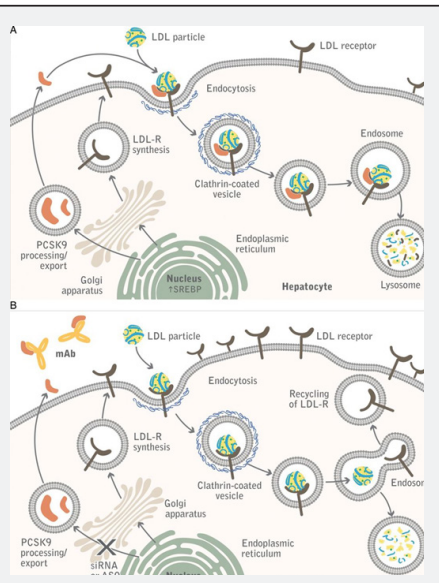

Figure 8: PSCK9 mode of action [64] 


\section{Cholesterylester Transfer Protein (CETP) Inhibitors}

\section{Mechanism of action}

CETP induces the transport of cholesteryl esters and TG from HDL molecules to atherogenic molecules, such as the ApoBcontaining lipoproteins [15,69-73] (Table 11).

Notes:

a) Dalcetrapib in patients with recent acute coronary syndrome events showed poor efficacy when added to standard of care treatment, failing to reduce CVD recurrence [74].

b) Evacetrapib was also abandoned due to lack of improved CVD outcomes [75].

c) TA-8995 has good results on lipid metabolism $[75,74,76]$.

\section{ATP-Citrate Lyase (ACL) Inhibitor}

\section{Mechanism of action:}

The ACL inhibitor ETC-1002 (bempedoic acid) has been found to lower cholesterol biosynthesis by depriving cells of the necessary substrates $[77,56]$.

Reduce C-reactive protein levels, better CVD outcomes may be possible through its implication in pro-inflammation processes [78].

\section{Plaque Regression Treatment (rHDL) in FH:}

\section{Mechanism of action}

Intravenous infusion of reconstituted HDL or an HDL-mimetic particle (CER-001) has shown encouraging results in reversing coronary atherosclerotic damage $[15,79]$.

Acts potentially by promoting reverse cholesterol transport and increasing the concentration of ApoA-I $[15,74]$.

\section{Surgical Therapy in FH}

a) Ileal bypass and liver transplantation could be options in patients at increased CVD risk who fail to reach the treatment targets or tolerate conventional treatment options [15,80-82].

b) Portacaval shunt can reduce the absorption of cholesterol and enhance bile acid excretion [83].

\section{Gene-Targeted Therapy in FH}

Genetic therapy may offer a promising approach for the treatment of FH in the near future [71,84].

\section{Conclusion}

Due to the FH-related high CVD morbidity and mortality, early prevention and effective management of these patients is essential through organized primary care and/or Lipid Specialist care centers. Current research further focuses on new monoclonal antibodies/genetic targeting approaches which may offer novel options in order to significantly lower LDL and prevent/reduce ASCVD in FH.

\section{References}

1. Austin MA, Hutter CM, Zimmern RL, Humphries SE (2004) Familial hypercholesterolemia and coronary heart disease: a HuGE association review. Am J Epidemiol 160(5): 421-429.

2. McLaughlin CL. Development of novel therapeutic approaches for the reduction of apolipoprotein B expression (Doctoral dissertation, Department of Cardiovascular Sciences).

3. Ramasamy I (2016) Update on the molecular biology of dyslipidemias. Clin Chim Acta 454: 143-185.

4. Sniderman AD, Tsimikas S, Fazio S (2014) The severe hypercholesterolemia phenotype: clinical diagnosis, management, and emerging therapies. J Am Coll Cardiol 63(19): 1935-1947.

5. Fredrickson DS, Levy RI, Lees RS (1967) Fat transport in lipoproteinsan integrated approach to mechanisms and disorders. N Engl J Med 276(1): 34-44.

6. Farmer JA, Gotto AM (1996) Choosing the right lipid-regulating agent. Drugs 52(5): 649-661.

7. Nordestgaard BG, Chapman MJ, Humphries SE, Ginsberg HN, Masana L, et al. (2013) Familial hypercholesterolaemia is underdiagnosed and undertreated in the general population: guidance for clinicians to prevent coronary heart disease: consensus statement of the European Atherosclerosis Society. Eur Heart J 34(45): 3478-3490.

8. Austin MA, Hutter CM, Zimmern RL, Humphries SE (2004) Genetic causes of monogenic heterozygous familial hypercholesterolemia: a HuGE prevalence review. Am J Epidemiol 160(5): 407-420.

9. Calandra S, Tarugi P, Speedy HE, Dean AF, Bertolini S, et al. (2011) Mechanisms and genetic determinants regulating sterol absorption, circulating LDL levels, and sterol elimination: implications for classification and disease risk. J Lipid Res 52(11): 1885-1926.

10. Defesche JC (2004) Low-density lipoprotein receptor-its structure, function, and mutations. Semin Vasc Med 4(1): 5-11.

11. Benn M, Nordestgaard BG, Jensen JS, Grande P, Sillesen H, et al (2005) Polymorphism in APOB associated with increased low-density lipoprotein levels in both genders in the general population. J Clin Endocrinol Metab 90(10): 5797-5803.

12. Abifadel M, Varret M, Rabès JP, Allard D, Ouguerram K, et al. (2003) Mutations in PCSK9 cause autosomal dominant hypercholesterolemia. Nat Genet 34(2): 154-156.

13. Garcia CK, Wilund K, Arca M, Zuliani G, Fellin R, et al. (2001) Autosomal recessive hypercholesterolemia caused by mutations in a putative LDL receptor adaptor protein. Science 292(5520): 1394-1398.

14. Cuchel M, Bruckert E, Ginsberg HN, Raal FJ, Santos RD, et al. (2014) Homozygous familial hypercholesterolaemia: new insights and guidance for clinicians to improve detection and clinical management. A position paper from the Consensus Panel on Familial Hypercholesterolaemia of the European Atherosclerosis Society. Eur Heart J 35(32): 2146-2157.

15. Hovingh GK, Davidson MH, Kastelein JJ, O'connor AM (2013) Diagnosis and treatment of familial hypercholesterolaemia. Eur Heart J 34(13): 962-971.

16. Brunzell JD, Davidson M, Furberg CD, Goldberg RB, Howard BV, et al. (2008) Lipoprotein management in patients with cardiometabolic risk: consensus statement from the American Diabetes Association and the American College of Cardiology Foundation. Diabetes care 31(4): 811-822. 
17. Stone NJ, Robinson JG, Lichtenstein AH, Merz CN, Blum CB, et al. (2014) 2013 ACC/AHA guideline on the treatment of blood cholesterol to reduce atherosclerotic cardiovascular risk in adults: a report of the American College of Cardiology/American Heart Association Task Force on Practice Guidelines. J Am Coll Cardiol 63(25 Pt B): 2889-2934.

18. Rao DP, Dai S, Lagacé C, Krewski D (2014) Metabolic syndrome and chronic disease. Chronic Dis Inj Can 34(1): 36-45.

19. Ngo-Metzger Q, Zuvekas SH, Bierman AS (2018) Estimated Impact of US Preventive Services Task Force Recommendations on Use and Cost of Statins for Cardiovascular Disease Prevention. J Gen Intern Med 33(8): 1317-1323.

20. Curry SJ, Krist AH, Owens DK, Barry MJ, Caughey AB, et al. (2018) Risk assessment for cardiovascular disease with nontraditional risk factors: US preventive services task force recommendation statement. JAMA 320(3): 272-280.

21. Pignone MP, Phillips CJ, Atkins D, Teutsch SM, Mulrow CD, et al. (2001) Screening and treating adults for lipid disorders. Am J Prev Me 20(3 Suppl): 77-89.

22. Huang J, Frohlich J, Ignaszewski AP (2011) The impact of dietary changes and dietary supplements on lipid profile. Can J Cardiol 27(4): 488-505.

23. Gupta AK, Savopoulos CG, Ahuja J, Hatzitolios AI (2011) Role of phytosterols in lipid-lowering: current perspectives. QJM 104(4): 301308

24. Jenkins DJ, Jones PJ, Lamarche B, Kendall CW, Faulkner D, et al. (2011) Effect of a dietary portfolio of cholesterol-lowering foods given at 2 levels of intensity of dietary advice on serum lipids in hyperlipidemia: a randomized controlled trial. JAMA 306(8): 831-839.

25. National Cholesterol Education Program (NCEP) Expert Panel on Detection, Evaluation, and Treatment of High Blood Cholesterol in Adults (Adult Treatment Panel III) (2002) Third report of the National Cholesterol Education Program (NCEP) expert panel on detection, evaluation, and treatment of high blood cholesterol in adults (Adult Treatment Panel III) final report. Circulation 106(25): 3143-3421.

26. Anderson TJ, Gregoire J, Pearson GJ, Barry AR, Couture P, et al. (2016) 2016 Canadian Cardiovascular Society guidelines for the management of dyslipidemia for the prevention of cardiovascular disease in the adult. Can J Cardiol 32(11): 1263-1282.

27. Sathiyakumar V, Park J, Golozar A, Lazo M, Quispe R, et al. (2018) Fasting versus nonfasting and low-density lipoprotein cholesterol accuracy. Circulation 137(1): 10-19.

28. Cooper GR, Myers GL, Smith SJ, Schlant RC (1992) Blood lipid measurements: variations and practical utility. JAMA 267(12): 16521660.

29. Folsom AR, Kuba K, Leupker RV, Jacobs DR, Frantz ID (1983) Lipid concentrations in serum and EDTA-treated plasma from fasting and nonfasting normal persons, with particular regard to high-density lipoprotein cholesterol. Clin Chem 29(3): 505-508.

30. Ryder RE, Hayes T, Mulligan IP, Kingswood JC, Williams S, et al. (1984) How soon after myocardial infarction should plasma lipid values be assessed?. Br Med J (Clin Res Ed) 289(6459): 1651-1653.

31. Diekman T, Lansberg PJ, Kastelein JJ, Wiersinga WM (1995) Prevalence and correction of hypothyroidism in a large cohort of patients referred for dyslipidemia. Arch Intern Med 155(14): 1490-1495.

32. Catapano AL, Graham I, De Backer G, Wiklund O, Chapman MJ, et al. (2017) 2016 ESC/EAS Guidelines for the Management of Dyslipidaemias. Rev Esp Cardiol (Engl Ed) 70(2): 115.

33. Feingold KR, Grunfeld C (2018) Approach to the Patient with Dyslipidemia. MDText. com, Inc.
34. Piepoli MF, Hoes AW, Agewall S, Albus C, Brotons C, et al. (2016) Guidelines: Editor's choice: 2016 European Guidelines on cardiovascular disease prevention in clinical practice: The Sixth Joint Task Force of the European Society of Cardiology and Other Societies on Cardiovascular Disease Prevention in Clinical Practice (constituted by representatives of 10 societies and by invited experts) Developed with the special contribution of the European Association for Cardiovascular Prevention \& Rehabilitation (EACPR). Eur Heart J 37(29): 2315-2381.

35. Grundy SM, Stone NJ, Bailey AL, Beam C, Birtcher KK, et al. (2019) 2018 AHA/ACC/AACVPR/AAPA/ABC/ACPM/ADA/AGS/APhA/ASPC/NLA/ PCNA guideline on the management of blood cholesterol: a report of the American College of Cardiology/American Heart Association Task Force on Clinical Practice Guidelines. J Am Coll Cardiol 73(24): e285350.

36. Reiner Ž, Catapano AL, De Backer G, Graham I, Taskinen MR, et al (2011) ESC/EAS Guidelines for the management of dyslipidaemias: the Task Force for the management of dyslipidaemias of the European Society of Cardiology (ESC) and the European Atherosclerosis Society (EAS). Eur Heart J 32(14): 1769-1818.

37. Bouhairie VE, Goldberg AC (2015) Familial hypercholesterolemia. Cardiol Clin 33(2): 169-179.

38. Friday KE, Failor RA, Childs MT, Bierman EL (1991) Effects of n-3 and n-6 fatty acid-enriched diets on plasma lipoproteins and apolipoproteins in heterozygous familial hypercholesterolemia. Arterioscler Thromb 11(1): 47-54.

39. Sala-Vila A, Cofán M, Mateo-Gallego R, Cenarro A, Civeira F, et al. Eicosapentaenoic acid in serum phospholipids relates to a less atherogenic lipoprotein profile in subjects with familial hypercholesterolemia. J Nutr Biochem 24(9): 1604-1608.

40. Pase MP, Grima NA, Sarris J (2011) Do long-chain n-3 fatty acids reduce arterial stiffness? A meta-analysis of randomised controlled trials. Br Nutr 106(7): 974-980.

41. Chan DC, Pang J, Barrett PH, Sullivan DR, Mori TA, et al. (2016) Effect of omega-3 fatty acid supplementation on arterial elasticity in patients with familial hypercholesterolaemia on statin therapy. Nutr Metab Cardiovasc Dis 26(12): 1140-1145.

42. Grey A, Bolland M (2014) Clinical trial evidence and use of fish oil supplements. JAMA Intern Med 174(3): 460-462.

43. Anguita M, Alegría E, Barrios V, Casasnovas JA, Escobar C, et al. (2011) Comments on the 2011 ESC/EAS guidelines for the management of dyslipidemias. A report of the Task Force of the Clinical Practice Guidelines Committee of the Spanish Society of Cardiology. Revista Española de Cardiología (English Edition) 64(12): 1090-1095.

44. Cuchel M, Bruckert E, Ginsberg HN, Raal FJ, Santos RD, et al (2014) Homozygous familial hypercholesterolaemia: new insights and guidance for clinicians to improve detection and clinical management. A position paper from the Consensus Panel on Familial Hypercholesterolaemia of the European Atherosclerosis Society. Eur Heart J 35(32): 2146-2157.

45. Cuchel M, Meagher EA, du Toit Theron H, Blom DJ, Marais AD, et al. (2013) Efficacy and safety of a microsomal triglyceride transfer protein inhibitor in patients with homozygous familial hypercholesterolaemia: a single-arm, open-label, phase 3 study. Lancet 381(9860): 40-46.

46. Stefanutti C, Morozzi C, Di Giacomo S, Sovrano B, Mesce D, et al. (2016) Management of homozygous familial hypercholesterolemia in realworld clinical practice: a report of 7 Italian patients treated in Rome with lomitapide and lipoprotein apheresis. J Clin Lipidol 10(4): 782789.

47. Roeters van Lennep J, Averna M, Alonso R (2015) Treating homozygous familial hypercholesterolemia in a real-world setting: experiences with lomitapide. J Clin Lipidol 9(4): 607-617. 
48. Najam O, Ray KK (2015) Familial hypercholesterolemia: a review of the natural history, diagnosis, and management. Cardiol Ther 4(1): 25-38.

49. Hegele RA, Gidding SS, Ginsberg HN, McPherson R, Raal FJ, et al. (2015) Nonstatin low-density lipoprotein-lowering therapy and cardiovascular risk reduction-statement from ATVB council Arterioscler Thromb Vasc Biol 35(11): 2269-2280.

50. Raal FJ, Braamskamp MJ, Selvey SL, Sensinger CH, Kastelein JJ (2016) Pediatric experience with mipomersen as adjunctive therapy for homozygous familial hypercholesterolemia. J Clin Lipidol 10(4): 860 869

51. Akdim F, Visser ME, Tribble DL, Baker BF, Stroes ES, et al. (2010) Effect of mipomersen, an apolipoprotein B synthesis inhibitor, on low-density lipoprotein cholesterol in patients with familial hypercholesterolemia. Am J Cardiol 105(10): 1413-1419.

52. Raal FJ, Santos RD, Blom DJ, Marais AD, Charng MJ, et al. (2010) Mipomersen, an apolipoprotein B synthesis inhibitor, for lowering of LDL cholesterol concentrations in patients with homozygous familial hypercholesterolaemia: a randomised, double-blind, placebocontrolled trial. Lancet 375(9719): 998-1006.

53. Visser ME, Akdim F, Tribble DL, Nederveen AJ, Kwoh TJ, et al. (2010) Effect of apolipoprotein-B synthesis inhibition on liver triglyceride content in patients with familial hypercholesterolemia. J Lipid Res 51(5): 1057-1062.

54. Hartgers ML, Ray KK, Hovingh GK (2015) New approaches in detection and treatment of familial hypercholesterolemia. Curr Cardiol Rep 17(12): 109.

55. Villicev CM, Freitas FR, Aoki MS, Taffarel C, Scanlan TS, et al. (2007) Thyroid hormone receptor $\beta$-specific agonist GC- 1 increases energy expenditure and prevents fat-mass accumulation in rats. J Endocrinol 193(1): 21-29.

56. Lammel Lindemann J, Webb P (2016) Sobetirome: the past, present and questions about the future. Expert Opin Ther Targets 20(2): 145149

57. Lin JZ, Martagón AJ, Hsueh WA, Baxter JD, Gustafsson JÅ, et al. (2012) Thyroid hormone receptor agonists reduce serum cholesterol independent of the LDL receptor. Endocrinology 153(12): 6136-6144.

58. Sjouke B, Langslet G, Ceska R, Nicholls SJ, Nissen SE, et al. (2014) Eprotirome in patients with familial hypercholesterolaemia (the AKKA trial): a randomised, double-blind, placebo-controlled phase 3 study. Lancet Diabetes Endocrinol 2(6): 455-463.

59. Huff MW, Assini JM, Hegele RA (2014) Gene therapy for hypercholesterolemia: sweet dreams and flying machines. Circ Res 115(6): 542-545.

60. Ferdinand KC, Nasser SA (2015) PCSK9 inhibition: discovery, current evidence, and potential effects on LDL-C and Lp (a). Cardiovasc Drugs Ther 29(3): 295-308.

61. Alonso R, Mata P, Muniz O, Fuentes-Jimenez F, Díaz JL, et al. (2016) PCSK9 and lipoprotein (a) levels are two predictors of coronary artery calcification in asymptomatic patients with familial hypercholesterolemia. Atherosclerosis 254: 249-253.

62. Zhang Y, Eigenbrot C, Zhou L, Shia S, Li W, et al. (2014) Identification of a small peptide that inhibits PCSK9 protein binding to the low density lipoprotein receptor. J Biol Chem 289(2): 942-955.

63. Lambert G, Sjouke B, Choque B, Kastelein JJ, Hovingh GK (2012) The PCSK9 decade thematic review series: new lipid and lipoprotein targets for the treatment of cardiometabolic diseases. J Lipid Res 53(12): 2515-2524

64. Ito MK, Santos RD (2017) PCSK9 inhibition with monoclonal antibodies: modern management of hypercholesterolemia. J Clin Pharmacol 57(1): 7-32.
65. Gouni-Berthold I, Descamps OS, Fraass U, Hartfield E, Allcott K, et al. (2016) Systematic review of published Phase 3 data on anti-PCSK9 monoclonal antibodies in patients with hypercholesterolaemia. Br J Clin Pharmacol 82(6): 1412-1443.

66. Wiggins BS, Senfield J, Kassahun H, Lira A, Somaratne R (2018) Evolocumab: considerations for the management of hyperlipidemia. Curr Atheroscler Rep 20(4): 17.

67. Farnier M, Colhoun HM, Sasiela WJ, Edelberg JM, Asset G, et al. (2017) Long-term treatment adherence to the proprotein convertase subtilisin/kexin type 9 inhibitor alirocumab in 6 ODYSSEY Phase III clinical studies with treatment duration of 1 to 2 years. J Clin Lipidol 11(4): 986-997.

68. Greig SL, Deeks ED (2016) Alirocumab: a review in hypercholesterolemia. Am J Cardiovasc Drugs 16(2): 141-152.

69. Blom DJ, Hala T, Bolognese M, Lillestol MJ, Toth PD, et al. (2014) A 52week placebo-controlled trial of evolocumab in hyperlipidemia. $\mathrm{N}$ Engl J Med 370(19): 1809-1819.

70. Dixon DL, Trankle C, Buckley L, Parod E, Carbone S, et al. (2016) A review of PCSK9 inhibition and its effects beyond LDL receptors. J Clin Lipidol 10(5): 1073-1080.

71. Mytilinaiou M, Kyrou I, Khan M, Grammatopoulos DK, Randeva HS (2018) Familial Hypercholesterolemia: New Horizons for Diagnosis and Effective Management. Front Pharmacol 9: 707.

72. Barter PJ, Caulfield M, Eriksson M, Grundy SM, Kastelein JJ, et al. (2007) Effects of torcetrapib in patients at high risk for coronary events. N Engl J Med 357(21): 2109-2122.

73. Schwartz GG, Olsson AG, Abt M, Ballantyne CM, Barter PJ, et al (2012) Effects of dalcetrapib in patients with a recent acute coronary syndrome. N Engl J Med 367(22): 2089-2099.

74. Filippatos TD, Klouras E, Barkas F, Elisaf M (2016) Cholesteryl ester transfer protein inhibitors: challenges and perspectives. Expert Rev Cardiovasc Ther 14(8): 953-962.

75. Hovingh GK, Kastelein JJ, Van Deventer SJ, Round P, Ford J, et al. (2015) Cholesterol ester transfer protein inhibition by TA-8995 in patients with mild dyslipidaemia (TULIP): a randomised, double-blind, placebo-controlled phase 2 trial. Lancet 386(9992): 452-460.

76. van Capelleveen JC, Kastelein JJ, Zwinderman AH, van Deventer SJ, Collins HL, et al. (2016) Effects of the cholesteryl ester transfer protein inhibitor, TA-8995, on cholesterol efflux capacity and high-density lipoprotein particle subclasses. J Clin Lipidol 10(5): 1137-1144.

77. Bilen O, Ballantyne CM (2016) Bempedoic acid (ETC-1002): an investigational inhibitor of ATP citrate lyase. Curr Atheroscler Rep 18(10): 61.

78. Penson P, McGowan M, Banach M (2017) Evaluating bempedoic acid for the treatment of hyperlipidaemia. Expert Opin Investig Drugs 26(2): 251-259.

79. Kootte RS, Smits LP, van der Valk FM, Dasseux JL, Keyserling CH, et al. (2015) Effect of open-label infusion of an apolipoprotein AI-containing particle (CER-001) on reverse cholesterol transport and artery wall thickness in patients with familial hypo-alphalipoproteinemia. J Lipid Res 56(3): 703-712.

80. Goldberg AC, Hopkins PN, Toth PP, Ballantyne CM, Rader DJ, et al. (2011) Familial hypercholesterolemia: screening, diagnosis and management of pediatric and adult patients: clinical guidance from the National Lipid Association Expert Panel on Familial Hypercholesterolemia. J Clin Lipidol 5(3): S1-S8.

81. Martinez M, Brodlie S, Griesemer A, Kato T, Harren P, et al. (2016) Effects of liver transplantation on lipids and cardiovascular disease in children with homozygous familial hypercholesterolemia. Am J Cardiolo 118(4): 504-510. 
82. Mansoorian M, Kazemi K, Nikeghbalian S, Shamsaeefar A, Mokhtari M, et al. (2015) Liver transplantation as a definitive treatment for familial hypercholesterolemia: a series of 36 cases. Pediatr Transplant 19(6): 605-611.

83. Bilheimer DW, Goldstein JL, Grundy SM, Brown MS (1975) Reduction in cholesterol and low-density lipoprotein synthesis after portacaval shunt surgery in a patient with homozygous familial hypercholesterolemia. J Clin Invest 56(6):1420-1430.

84. Zheng KH, van der Valk FM, Smits LP, Sandberg M, Dasseux JL, et al. (2016) HDL mimetic CER-001 targets atherosclerotic plaques in patients. Atherosclerosis 251: 381-388.

Your next submission with Juniper Publishers
will reach you the below assets
- Quality Editorial service
- Swift Peer Review
- Reprints availability
- E-prints Service
- Manuscript Podcast for convenient understanding
- Global attainment for your research
- Manuscript accessibility in different formats
( Pdf, E-pub, Full Text, Audio)
- Unceasing customer service
Track the below URL for one-step submission
https://juniperpublishers.com/online-submission.php

